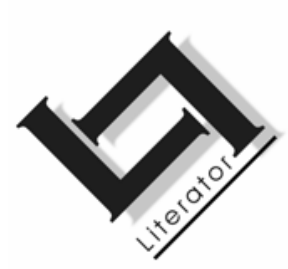

\title{
Van Tempeltronk tot katedraal: die kruisweg van Lodewyk XVII
}

\author{
Naòmi Morgan \\ Departement Afrikaans, Nederlands, Duits \& Frans \\ Universiteit van die Vrystaat \\ BLOEMFONTEIN \\ E-pos: morgann.HUM@mail.uovs.ac.za
}

\begin{abstract}
From the Temple to the cathedral: the calvary of Louis XVII

In 2004, more than 200 years after his death in the Temple prison, the heart of Louis XVII, the successor to France's last king of the Ancien Régime, Louis XVI, was buried in the royal necropolis of Saint-Denis. Despite numerous publications on the destiny of the Little Prince, the chronology of his short life was not determined by historians and biographers, but by scientists who, in 2000, performed DNA tests on the petrified organ, which was miraculously preserved. Before this date, the biographies of the many pretenders to Louis XVII's throne (that of Naundorff in particular) were better-known than the lifehistory of Marie Antoinette's youngest son. Since then, various publications have changed this state of affairs, including an historical novel by one of France's most knowledgeable authors on the monarchy of the 17th and 18th centuries and a biographical novel by a member of the Bourbon family. Antonia Fraser's (2001) biography on Marie Antoinette and Sofia Coppola's (2006) film on her life have rekindled interest in the events of the French revolution. The story of Louis XVII, who was used as a pawn by the revolutionaries, is one the most tragic of that period in the country's history. This article provides an overview of key events gleaned from various sources, translated into Afrikaans for the first time.
\end{abstract}




\section{Opsomming}

\section{Van Tempeltronk tot katedraal: die kruisweg van Lodewyk XVII1}

In 2004, meer as 200 jaar na sy dood in die Tempeltronk, is die hart van Lodewyk XVII, die troonopvolger van die laaste Franse koning van die Ancien Régime, Lodewyk XVI, in die koninklike nekropolis van Saint-Denis ${ }^{2}$ te ruste gelê. Ten spyte van 'n groot aantal publikasies oor die lot van die Klein Prinsie, was dit nie historici en biograwe wat uiteindelik die chronologie van sy kort lewe vasgelê het nie, maar wetenskaplikes wat in 2000 DNS-toetse uitgevoer het op die versteende orgaan, wat wonderbaarlik bewaar gebly het. Voor hierdie datum was die biografieë van die vele aanspraakmakers op die troon van Lodewyk XVII (veral dié van Naundorff) meer bekend as die lewensgeskiedenis van Marie Antoinette se jongste seun. Sedertdien het verskeie publikasies die lig gesien, onder andere 'n historiese roman deur een van Frankryk se grootste kenners van die sewentiende- en agtiende-eeuse monargie, en 'n biografiese roman deur 'n lid van die Bourbon-familie. Antonia Fraser (2001) se biografie oor Marie Antoinette en Sofia Coppola (2006) se film oor haar lewe het opnuut belangstelling aangewakker in die gebeure van die Franse Rewolusie. Die verhaal van Lodewyk XVII, wat as 'n pion deur die rewolusionêre gebruik is, is een van die mees tragiese van daardie tydperk in die geskiedenis. In hierdie artikel word 'n oorsig gegee van daardie sleutelgebeure, afkomstig uit verskeie bronne wat vir die eerste keer in Afrikaans vertaal is.

Dis hier waar die klein prinsie op aarde verskyn en toe weer verdwyn het. [...] As jy miskien daarlangs gaan, moet asseblief nie haastig wees nie, talm 'n rukkie onder die ster! ${ }^{3}$

(De Saint-Exupéry, 1979)

1 Ek bedank graag dr. E.M. Visagie van die Afdeling Frans, UVS, vir die proeflees van die vertalings van Frans na Afrikaans.

2 Die twee spellings van Saint-Denis/Denys in hierdie artikel volg die konvensie van die bronne: eersgenoemde verwys na die Basilika-katedraal, en laasgenoemde na die privaat-organisasie wat omsien na die koninklike nekropolis binne dieselfde katedraal.

3 C'est ici que le petit prince a apparu sur terre, puis disparu. [...] Et, s'il vous arrive de passer par là, je vous en supplie, ne vous pressez pas, attendez un peu juste sous l'étoile! (Alle vertalings uit Frans na Afrikaans deur N. Morgan.) 


\section{Inleiding}

Op 8 Junie 2004 is die hart van Lodewyk-Karel van Bourbon tydens 'n plegtige seremonie in die Saint-Denis-katedraal in Parys, in die mausoleum van die Franse konings ter aarde bestel - 200 jaar na sy dood.

$\mathrm{Na}$ die teregstelling van die koning op 21 Januarie 1793, is die enigste oorlewende seun van Lodewyk XVI en Marie Antoinette op beskeie wyse as Lodewyk XVII deur familielede in die Tempeltronk ${ }^{4}$ erken. Sy "troonsbestyging" is verwelkom deur onder andere Spanje, Engeland, Oostenryk, Rusland, die Verenigde State van Amerika en die Pous. Dit sou Lodewyk-Karel se enigste eerbetoon wees. Sy liggaam is op 10 Junie 1795 om nege-uur die aand in 'n ongemerkte graf in die Sainte-Marguerite-begraafplaas (wat vandag onder die Saint-Bernard-straat lê) begrawe. Kort daarna is hy "gereïnkarneer" deur 'n horde vals kroonprinse (honderd-en-een, volgens die webwerf van die Mémorial de France à Saint-Denys; Cadbury, 2002:218 verwys selfs na 'n "Dauphin epidemic") wat sou aandring op 'n onderhoud met Marie-Thérèse of Madame Royale, sy enigste oorlewende suster. Dit sou die hoop van 'n wonderwerk by koningsgesindes en Europese anti-rewolusionêre magte laat opvlam, naamlik dat die tempelweeskind nie dood was nie, dat dit moontlik was om die tyd terug te draai en te verhinder, soos die Franse spreekwoord lui, dat die Rewolusie sy kinders, en veral Die Kind, eet.

Op agt jaar het Lodewyk-Karel as adellike en koninklike die ergste misdaad gepleeg deur 'n leuen te vertel en sodoende sy moeder en tante te verraai. Sy getuienis teen veral sy moeder (wat aan hom voorgesê is deur dieselfde rewolusionêre wat die seuntjie op 3 Julie 1793 van haar weggeskeur het) was bedoel om die beeld van 'n skaamtelose, losbandige vrou verder te versterk. Marie-Thérèse, wat in 1814 met die Restauration ${ }^{5}$ na Frankryk sou terugkeer, sou nooit vergeet dat haar broer se woorde hulle moeder en tante na die guillotine gestuur het nie.

4 Die Tempeltronk in Parys was oorspronklik 'n dertiende-eeuse Tempelierklooster wat ook as vesting gebruik is. Gedurende die Rewolusie is die koninklike familie daar gevange gehou.

5 'n Term wat gebruik word om Frankryk se monargistiese politieke régime vanaf April 1814 tot Julie 1830 te beskryf. 
Die seremonie van 2004 het gevolg op die uitslae van DNS-toetse in 2000 wat bewys het dat die hart, wat tydens die lykskouing op 9 Junie 1795 deur dr. Pelletan 6 gesteel is, geneties tot die BourbonHabsbourg-lyn behoort. Die lot van Lodewyk-Karel is een van die Rewolusie se mees tragiese verhale.

\section{Kroniek van 'n vroeë dood}

Daar bestaan verskeie portrette van Lodewyk-Karel van Bourbon, waarvan sommige selfs geteken is tydens sy gevangenskap in die Tempeltronk. Daar is Kucharski se portret van 'n jong volwassene in uniform (sien portret 1 aan die einde van hierdie artikel), 'n pragtige portret deur David (portret 2) en een deur Vien (portret 3) wat in die Tempeltronk geskilder is: Lodewyk-Karel is skaars herkenbaar, sy wenkbroue is gelig soos iemand wat permanent op sy hoede is, en die streng haarstyl van 'n vyftiende-eeuse Florentynse edelknaap kontrasteer met sy verwilderde uitdrukking. Die mees verontrustende beeld is egter die sepia-portret wat Moriès (portret 4) in die Tempeltronk geskilder het van 'n volwasse gesig wat byna agter die kraag van 'n kindermantel verberg word. Hoewel die maak van afbeeldings binne die Tempeltronk verbode was, is die meeste van hierdie portrette in opdrag van die rewolusionêre Convention ${ }^{7}$ gedoen, miskien om die publieke mening met die beeld van ' $n$ verswakte, gedegenereerde kroonprins te beïnvloed.

Lodewyk-Karel van Bourbon sou 'n kwart van sy lewe in die tronk deurbring. Hy sou nooit die troon bestyg nie. Van sy geboorte af is die kind omring deur goewernantes, hofdames, geselskapsdames, kleedsters en voedsters. Sy opvoeding was modern vir daardie tyd en sosiale klas: teen die tradisie in sou albei sy ouers waak oor sy skoling en welstand. Gedurende sy leeftyd was daar reeds botsende berigte oor sy gesondheid: die enfant de paysan of "boerseun" (volgens Mercy-Argenteau, die Oostenrykse ambassadeur in Frankryk; Petrie, 1995:21) is ook beskryf as "ragities", 'n "sifilislyer" ('n xenofobiese verwysing na sy Habsburgse herkoms) en selfs as "epilepties" (volgens sy moeder het hy "sedert sy inenting [teen pokke] senu-aanvalle gekry wat soos epilepsie lyk"; Petrie,

6 Die chirurg Philippe-Jean Pelletan is kort voor Lodewyk-Karel se dood deur die rewolusionêre Comité de sûreté as die kroonprins se arts aangewys.

7 Die Rewolusionêre vergadering wat op 21 September 1792 in die lewe geroep is, die Eerste Republiek uitgeroep het en Frankryk regeer het tot 26 Oktober 1795. 
1995:63). Verbasend genoeg het sy fisiese en psigiese gesondheid staande gebly tydens dramatiese gebeure in sy lewe. Hierdie gebeure was onder andere die koninklike familie se gedwonge vertrek van Versailles na Parys in 1789; die vlug na Varennes en die moeilike terugkeer na die Franse hoofstad nadat die ontsnappingspoging gefnuik is; die gepeupel se bestorming van die Tuileries terwyl Marie Antoinette met haar twee oorblywende kinders onder 'n tafel weggekruip het; die opsluiting in die Tempeltronk en die makabere parade van terreurslagoffers voor hulle tronkvensters, waarvan die skokkendste die erbarmlike oorblyfsels van die prinses van Lamballe 8 was. Die klam, bedompige toring, die kind se nuwe tuiste, het uiteindelik sy brose gestel verswak. Die beskrywing van die historiese romanskryfster Françoise Chandernagor (2002:36) lui soos volg:

dit was nooit die bedoeling dat hierdie bergtop bewoon moes word nie. Dit was eers 'n uitkyktoring. Toe 'n brandkluis. Dit was 'n opgaarplek vir goudstawe en argiewe ...9

Hier sou Lodewyk-Karel leer om eensaamheid te verduur. In die Tempeltronk het Lodewyk XVI aanvanklik vir hom lees-, skryf- en aardrykskundelesse gegee wanneer die gesin met etenstye bymekaar gekom het. Vanaf 11 Desember 1792 is Lodewyk XVI van sy gesin en veral van sy seun afgesonder. "Klein Lodewyk", 'n intelligente, ondeunde, blonde seuntjie met blou oë, die enigste lid van die koninklike familie wat die volk se hart kon vermurwe, moes aanleer om geluidloos te lewe en hy sou uiteindelik 'n uiters senuweeagtige kind word. Aanvanklik is 'n uur wandeltyd aan die gevangenes toegestaan, 'n toegewing wat later teruggetrek is. Gevolglik kon Lodewyk-Karel op tienjarige ouderdom nie meer loop nie. Die laaste van sy bewaarders moes hom buite in die arms ronddra nadat sekere toegewings weer na Robespierre se dood gemaak is.

Die tweede deel van sy biografie vertel die verhaal van 'n eensame, mishandelde kind. Pogings om die Bourbons te bevry (deur onder andere Toulan, die Baron van Batz, maarskalk Jarjayes en Lady Charlotte Atkins), sou misluk. Louis d'Andigné (1765-1857), 'n

8 Marie-Thérèse Louise de Savoie-Carignan, een van Marie Antoinette se beste vriendinne, wat gedurende die September 1792-massamoorde wreedaardig gemartel en om die lewe gebring is.

9 [...] jamais ce piton n'avait été destiné à l'habitation. C'était d'abord un mirador. Puis un coffre-fort. On y entassait des lingots, des archives ... 
kontra-rewolusionêre generaal uit die Vendée, het vanaf 1794 tot 1795 maniere ondersoek om die kind te bevry, maar het gou besef dat dit nooit sou slaag nie. Indien Lodewyk XVII sou sterf, sou sy ooms, Provence en Artois, aanspraak kon maak op die troon. Daar was selfs onverifieerbare gerugte dat Provence 'n komplot gesmee het om die kroonprins om die lewe te bring. Hoewel daar na 1793 nog "Lank lewe Lodewyk XVII!" langs die valbyl gehoor is, is Lodewyk-Karel deur almal in die steek gelaat. Sy naasbestaandes was onseker of hy nog lewe; die Parysenaars het hom die laaste keer in Junie 1793, op pad na die Tempeltronk, gesien. Miskien het die lot van 'n "verraaier" niemand meer geïnteresseer nie.

Daar is verskeie bronne wat Lodewyk-Karel se sogenaamde "heropvoeding" deur die skoenmaker Antoine Simon en sy vrou MarieJeanne dokumenteer. Daar kan met 'n paar voorbeelde volstaan word om ' $n$ beeld van die Simon-egpaar te skets. Deur hulle toedoen ondergaan Lodewyk-Karel 'n metamorfose: sy rouklere word deur 'n Jakobynse uniform vervang en sy aristokratiese krulle word afgesny. Die rewolusionêre Convention se vrygewigheid ten spyt, word Lodewyk-Karel se klere al hoe minder gewas, sodat hy later oortrek is van ongediertes. Hy moet sy vader se lesse "afleer" (bladsye uit sy boeke word gebruik om Antoine se pyp aan te steek) en vulgêre soldateliedjies memoriseer. $\mathrm{Na}$ drie maande van dreigemente en vernederings was sy denkbeelde só vervorm dat hy "erken" het (deur die gebruik van onwaarskynlike terme soos "herhaaldelike bloedskande", wat onnatuurlik geklink het in die mond van 'n agtjarige kind) dat hy sedert sy sesde jaar seksueel deur sy moeder misbruik is.

Gedurende sy "regeringstydperk" het die jong "koning" net een dokument geteken, naamlik sy aanklag teen Marie Antoinette. Lodewyk-Karel se oefeningboeke toon dat hy 'n mooi handskrif gehad het; op die verdoemende dokument wat sy moeder na die guillotine sou stuur, is niks daarvan te bespeur nie. Dié agteruitgang is waarskynlik toe te skryf aan vrees of dronkenskap. Marie-Thérèse skryf in haar Mémoire (Cadbury, 2002:116):

Simon made him eat horribly and forced him to drink much wine, which he detested. All this gave him a fever ... and his health became totally out of order.

Ná Marie Antoinette se teregstelling in Oktober 1793, was die klein prinsie se enigste beloning vir sy verraad 'n verlaging in status: die koning van Frankryk sou soos 'n kneg stewels poets, bedpanne leegmaak en mense aan tafel bedien. Die sieklike seun se tydsaam- 
heid is gestraf met skoppe en slae. Hy sou al hoe minder praat, en uiteindelik byna afaties word. Toe die Simon-egpaar op 19 Januarie 1794 die Tempeltronk se diens verlaat het, het 'n legende ontstaan waarvolgens die kroonprins gered is deur sy bewaarder, wat hom in 'n wasgoedmandjie sou versteek het ('n onmoontlike scenario in die lig van die streng, onafgebroke bewaking van die potensiële troonopvolger; in September 1794 was daar byvoorbeeld, volgens Cadbury, 2002:155, vyfhonderd wagte om Lodewyk-Karel en sy suster te bewaak). Niemand sou Antoine se pos vul of verantwoordelikheid aanvaar vir die agtjarige seuntjie wat voortaan soos 'n gewone misdadiger behandel sou word nie:

Louis-Charles was to have all semblance of humanity stripped from him and had to face the most nightmarish treatment possible for a young child. As security was greatly increased around him, the child was effectively entombed alive (Cadbury, 2002:137).

Ná Robespierre se val in Julie 1794 is Lodewyk-Karel se kamerdeur uiteindelik oopgemaak. Die simpatieke nuwe bewaarder, Laurent, het verdunde sop voorgeskryf, en velroom vir die sterwende kind se ekseem. Lodewyk-Karel het toe nog nie geweet dat sy moeder en tante intussen tereggestel is nie. Op 8 Junie 1795, teen kwart voor drie die middag, het hy volgens oorlewering vir sy laaste bewaarder, Lasne, gefluister dat hy iets gehad het om vir hom te sê, maar "Meneer Karel" is kort daarna oorlede.

Marie-Thérèse, wat in 'n sel bokant dié van haar broer aangehou is, was onbewus van die lykskouing wat die artse besig was om op haar broer uit te voer. Sy is nie gevra om die liggaam uit te ken nie: sy was nie mondig nie, en die dekreet waarvolgens broer en suster verbied is om mekaar te sien, was steeds van krag. Sy sou eers op 20 Julie 1795 van haar broer, moeder en tante se dood hoor. Haar bondige beskrywing van sy lyding en dood in haar Mémoire ("I believe that no researches can show such barbarity to any other child", aangehaal in Cadbury, 2002:155) is waarskynlik gebaseer op gesprekke met bewaarders (veral Lasne en Gomin). Die twee artse (Jean-Baptiste-Eugénie Dumangin en Philippe-Jean Pelletan, bygestaan deur hulle kollegas Lassus en Jeanroy) het tot die gevolgtrekking gekom dat die kind dood is aan 'n "kliersiekte waaraan hy lank reeds gely het"10 (Petrie, 1995:247). 'n Bourbon- 
afstammeling sou in 2001 opmerk dat dit 'n hoogs simboliese diagnose was:

Die Latynse term 'scrofulae' beteken skrofulose. 'n Gesalfde koning het die vermoë gehad om hierdie siekte, wat wydverspreid in die koninkryk voorgekom het, te genees. Die Capetseun het beswyk aan 'n kliersiekte wat hy self sou kon genees. Lodewyk XVII is nie dood aan 'n siekte nie; hy is dood omdat hy onbewus van sy koningskap was $\mathbf{1 1}$ (De Bourbon Parme, 2001:104).

Die lykskouingverslag verwys na 'n abnormale groeiproses: Lodewyk-Karel het 'n tenger borskas, uitermate lang arms en uitgroeisels aan sy bene gehad; hierdie misvormde liggaam sou vir die rewolusionêre die inkarnasie wees van 'n regeringsvorm wat na 1 000 jaar tot 'n einde gekom het. Die verslag het die Rewolusie vrygespreek van alle blaam, asook van die klag van kindermishandeling:

Die enigste skuldige was die siekte self; 'n vae, geheimsinnige siekte wat lank reeds deel was van hierdie onbekende liggaam, selfs voordat hy in die tronk opgesluit is. Dit was trouens dieselfde beentering waaraan sy broer in 1789 oorlede is; die oorerflike infeksie is maar net van een kind na die volgende oorgedra12 (De Bourbon Parme, 2001:232).

Jeanroy, wat geassisteer het, het wel 'n betekenisvolle opmerking oor Lodewyk-Karel se brein gemaak:

[...] in more than forty years' exercise of his art, he had never seen the brain so well developed in a child that age (Cadbury, 2002:164).

Op 29 Maart 1817 (dus gedurende die Restauration) het Pelletan 'n verklaring in die teenwoordigheid van die Minister van Justisie, E.D. Pasquier, onderteken waarvan die terminologie aansienlik verskil

11 En latin, "scrofulae" signifie écrouelles. Le sacre donnait au roi le pouvoir de guérir cette maladie très répandue dans le royaume. L'enfant Capet a succombé à ce vice scrofuleux qu'il aurait dû guérir. Bien plus que de maladie, Louis XVII est mort de n'avoir pas su qu'il était roi.

12 La maladie était la seule coupable; une maladie informe et mystérieuse qui existait depuis longtemps dans ce corps inconnu, bien avant son arrivée à la prison. C'était d'ailleurs la même tuberculose osseuse qui avait emporté son frère en 1789, d'une contagion héréditaire à l'autre, il n'y avait que l'épaisseur du sang. 
het van die rewolusionêre woordeskat wat die kind gedurende sy gevangeskap moes aanhoor. Pelletan verwys daarin na die "deurlugtige spruit", "koninklike kind" en "jong koning" 13 (Petrie, 1995:247) wat weens mishandeling aan sy "skrofuleuse toestand"14 (Petrie, 1995:248) beswyk het. Pelletan bely ook sy orgaanroof: "[...] ek was stoutmoedig genoeg om die hart te buit. Ek het dit in die saagsels gerol waarmee die tafel bedek was en dit in my sak gedruk". 15 Sy bedoeling was om dit te "bewaar as 'n kultusvoorwerp, vir vereringsdoeleindes"16 (Petrie, 1995:248). Sodoende het Pelletan onbedoeld 'n eeu oue Franse ritueel uitgevoer:

For centuries it had been a tradition for the heart of a king to be embalmed and placed in the crypt of Saint Denis. It seems likely that Pelletan wanted to conserve this important relic of what he believed would be the last little king of France - after all, Louis XVI had been beheaded, his brothers had fled and the Republic was established (Cadbury, 2002:167).

Die hart is in gedistilleerde wyngees gedompel en die fles op die hoogste rak in Pelletan se studeerkamer versteek waar die ongebalsemde, vergete orgaan mettertyd kliphard geword het.

\section{Die koning is nie dood nie, lank lewe die klein koning}

Daar is drie verskillende datums by die Lodewyk-Karel-raaisel betrokke: die amptelike datum, waarvolgens die kroonprins op 8 Junie 1795 in die Tempeltronk oorlede is; ' $n$ beweerde sterfdatum in 1794, waarna sy plek ingeneem is deur 'n plaasvervanger wat in 1795 die lewe gelaat het; laastens het die kroonprins (volgens die oorlewingsteorie) glad nie in die Tempeltronk gesterf nie en leef die Franse monargie deur sy nasate voort. Die verskillende hipoteses oor die dood van Lodewyk XVII kan kortliks soos volg uiteengesit word (Petrie, 1995:11-12):

- Die amptelike doodsertifikaat (gedateer 8 Junie 1795) weerspieël die historiese werklikheid: Lodewyk XVII is dus wel in die Tempeltronk oorlede.

13 illustre rejeton, royal enfant, jeune roi.

14 état scrophuleux.

15 [...] j'osai m'emparer du cœur. Je le roulai dans le son qui couvrait la table et je le serrai dans ma poche.

$16[\ldots]$ conserver comme un objet de culte et de vénération. 
- Die kroonprins het aan siekte en mishandeling beswyk; 'n plaasvervanger het sy plek ingeneem. (Hierdie teorie berus op die ontdekking van 'n kindergeraamte wat aan die voet van die Tempeltronk in ongebluste kalk begrawe is.)

- Die kroonprins is waarskynlik vóór 1794 ontvoer; een of meer plaasvervangers het sy plek ingeneem. (Hierdie weergawe berus op 'n vergadering van die Directoire17 wat in 1796 in die geheim gehou is; in 1920 is bewys dat die daaropvolgende "verslag" 'n vervalsing was.)

- Lodewyk XVII het 'n nuwe identiteit aangeneem, dié van Carl Wilhelm Naundorff.

- Naundorff is die Pruisiese soldaat Carl Benjamin Werg en dus 'n bedrieër.

- Naundorff is 'n bedrieër.

Daar is verskeie opgrawings in die Sainte-Marguerite-begraafplaas gedoen waar Lodewyk XVII vermoedelik ter aarde bestel is: tussen 1805 en 1809, in 1816, 1846, 1894, 1904, 1970 en in 1979 - maar almal sonder sukses. Die verskyning van Regnault-Warin se roman, Le cimetière de la Madeleine, 18 het bygedra tot die legende dat die klein prinsie die Rewolusie oorleef het. Hierdie legende was die inspirasie vir 'n verskeidenheid boeke en gravures oor dié onderwerp:

[...] en als hij gered was, dan was de moord niet gepleegd. Zou hij zich nu bekendmaken, dan werd de schuld van wie hem erkenden gedelgd en daalde een miraculeuze kwijtschelding op het rouwmoedige Frankrijk neer (Zaal, 1995:42).

Die meeste tekste wat op verifieerbare bronne gebaseer was (soos dié van die historikus Alcide de Beauchesne) sou eers vanaf 1850 verskyn, sodat vals aanspraakmakers op die troon meer as 'n halfeeu lank carte blanche gehad het. Die geskiedenis sou veral die name van die bedrieërs Jean-Marie Hervagault, Mathurin Bruneau en die Baron van Richemont onthou. Mélanie en Maximin, kinders uit Grenoble, het voorgegee dat die Heilige Maria by La Salette geheime inligting oor Lodewyk XVII aan hulle toevertrou het. Karl

17 Die régime waarvolgens Frankryk vanaf 26 Oktober 1795 tot 9 November 1799 regeer is. Daarna is dit vervang deur die Consulat. 
Wilhelm Naundorff sou homself laat herdoop as Karel-Lodewyk van Bourbon: die inversie van die voorname was 'n idee van sy monargistiese vriende. Toevallig was dit ook die naam wat in Regnault-Warin se roman gebruik word.

Naundorff (wie se moedertaal Duits was) is die eerste bedrieër in die geskiedenis wat die vertroue kon wen van mense wie se taal hy nie eens gepraat het nie - sodanig dat tolkdienste nodig was. Sy Frans was 'n brabbeltaal, terwyl Lodewyk XVII dit gepraat en gehoor het tot sy tiende lewensjaar. Met sy kastaiingbruin krulhare en grys oë het Naundorff nie juis na die kroonprins gelyk nie; wat veral opvallend was, was die afwesigheid van enige Habsburgse gelaatstrekke of die Bourbonse neus (Petrie, 1995:140). In teenstelling hiermee verwys Cadbury (2002:257) na Naundorff se "remarkable physical resemblance to the Bourbons". Petrie het sy Ph.D. verwerf met 'n studie oor Naundorff en het die DNS-toetse geïnisieer wat tot die oplossing van die Lodewyk XVII-raaisel gelei het. Cadbury (2002:224) gee besondere erkenning aan Petrie in haar biografie, maar verklaar desnieteenstaande:

his credentials were to prove so compelling that he effectively founded a rival royal dynasty and his case was to be more disturbing to Marie-Thérèse than any of the others.

Naundorff en Lodewyk XVI het wel 'n belangstelling in uurwerke gedeel: in Duitsland het Naundorff horlosies op straat verkoop. Gedurende die Ancien régime het die aristokratiese Bourbon-profiel die waarde van die Franse geldeenheid gewaarborg; in 1824 is Lodewyk XVI se "seun" weens geldvervalsing gearresteer. In 1825 gebruik hy vir die eerste keer die naam Ludwig Bourbon, foneties gespel as "Ludewig Burbong" (Petrie, 1995:117). Vervolgens sou die doopname van sy aansienlike kroos sy metamorfose as Franse kroonprins bevestig: Amélie (Marie-Thérèse se skuilnaam op die vlug na Varennes), Karl Eduard (verfrans tot Karel Édouard) en Berta Juliane. Vanaf 1829 word die Habsburgse assonansie duidelik hoorbaar: Marie Antoinette, Ludwig Karl en Maria Theresa.

Lodewyk XVI was 'n begaafde slotmaker; sy "seun" Naundorff was 'n ontwerper van onsinkbare militêre skepe en vuurspuwende torings. In 1845 vestig hy hom in die Nederlande, waar hy sy "Bourbonse bom" demonstreer voor offisiere van die Militêre Akademie van Breda. Hy word 'n goed-besoldigde pos in Rotterdam aangebied, maar sterf skaars vier maande later (waarskynlik aan tifuskoors). Sy grafsteen in Delft (wat sedert 2000 apokrief is, net soos dié van die Baron van Richemont naby Lyon) lees: "Hier rus 
Lodewyk XVII, koning van Frankryk en Navarre, gebore te Versailles op 27 Maart 1785, oorlede te Delft op 10 Augustus 1845". 19 (De Bourbon Parme, 2001:29) Volgens sy Nederlandse doodsertifikaat was Naundorff inderdaad Lodewyk XVII. Sy nasate het hulle aanvanklik in Nederland gevestig en daarin geslaag om hulle geleende "Bourbon"-naam te wettig. Die Naundorff-mite word in stand gehou deur die publikasies van die Librairie de la Survivance in SaintSulpice, Parys, en deur die Institut Louis XVII wat in 1990 in die Rue des Moines, Parys, gestig is. Sedert 2000 word Naundorff se verhaal eerder as ' $n$ anekdote beskou en sy ondersteuners byna as 'n sekte.

Historici en biograwe het talle publikasies oor die Naundorff-geval die lig laat sien: in sy proefskrif20 van 1995 maak Petrie 'n lys van 2000 boeke en artikels oor hierdie onderwerp. Naundorff self sou geen "openbarings" maak wat nie na kontemporêre publikasies herlei kon word nie; sy grondige kennis van die tuine van Versailles, die binnekamer van Marie Antoinette se kamer en sy beskrywing van een van Lodewyk-Karel se kinderjassies het wel beïndruk. Bewerings dat hy sekere van Marie Antoinette se briewe asook Lodewyk XVI se trouring en seël in sy besit gehad het, kon nooit gestaaf word nie.

Die Engelse aktrise Charlotte Atkyns-Walpole is een van die talle ondersteuners van die Franse monargie wat hulle persoonlike fortuin gebruik het om die Bourbons van die guillotine te red en is sodoende deur genadelose opportuniste (wat meer in hulle geld as in ontsnappingspogings belang gestel het) uitgebuit. Lodewyk XVII se twee ooms, wat as Lodewyk XVIII en Karel X sou regeer, was nie haastig om die raaisel van die Tempelweeskind op te los nie indien die kroonprins nog gelewe het, sou dit hulle die troon kos. Hulle het ook gesloer om monargiste soos Atkyns-Walpole en Albouys ('n regter van Cahors en later 'n Naundorff-ondersteuner) te vergoed vir die koste wat hulle aangegaan het om die kind (of sy liggaam) te vind. Kort ná sy terugkeer uit ballingskap in Mei 1814, laat Lodewyk XVIII die (moontlike) oorblyfsels van sy broer en skoonsuster opgrawe en in die koninklike grafkelder van Saint-Denis herbegrawe. In Januarie 1815 word sy minister van binnelandse sake, die Hertog van Vaublanc, beveel om 'n ondersoek te loods na

19 Ici repose Louis XVII, roi de France et de Navarre, né à Versailles le 27 mars 1785, décédé à Delft le 10 août 1845. 
die lot van Lodewyk XVII. Danksy die pleidooie van Chateaubriand 21 in die Chambre des Pairs (Franse Senaat) op 9 Januarie 1816, neem opgrawings in die Sainte-Margueritebegraafplaas 'n aanvang op 21 Februarie 1816, maar sonder sukses. Die liggaam het vir altyd in 'n ongemerkte graf verdwyn. In 1832 spreek Chateaubriand in 'n brief aan Albouys die mening uit dat Lodewyk XVII waarskynlik lank reeds dood was en nooit sy identiteit sou kon bewys indien hy nog gelewe het nie. Die sterfdatum van Lodewyk XVII is nie in die Restauration se roukalender van die Ancien Régime herdenk nie; 'n gedenkteken vir die kroonprins is wel bestel, maar het nooit gerealiseer nie.

\section{Van biografie tot historiese roman}

Daar is min biografieë oor Lodewyk XVI, maar 'n oorvloed daarvan oor sy seun Lodewyk-Karel, hoewel dit in baie gevalle dié van vals kroonprinse is. Navorsing oor die lot van Lodewyk XVII is bemoeilik deur die verdwyning van een van die belangrikste bronne, die Tempeltronkregister, ná 8 April 1796, toe Étienne Lasne (die laaste bewaarder van Lodewyk XVII) dit aan die Minister van Binnelandse Sake, Bénézech, oorhandig het.

Historici en historiese romanskrywers staan voor dieselfde uitdaging, naamlik om figure uit die geskiedenis en hulle tydperk te laat herleef. Op die webwerf van die Mémorial22 word Françoise Chandernagor se La chambre (wat as "roman" op die omslag van die 2002-Gallimard uitgawe getipeer word) in dieselfde asem as die DNS-resultate van 2000 genoem. Die terreine van die historikus en die historiese romanskrywer oorvleuel uiteraard, soos blyk uit die spesiale uitgawes van akademiese tydskrifte rondom hierdie tema (vgl. bronne aangehaal in Morgan, 2001).

21 François René de Chateaubriand, Franse skrywer, ambassadeur en minister van buitelandse sake gedurende die Restauration.

22 II n'existe donc aucune possibilité d'erreur: le cœur expertisé en 2000 est bien celui de Louis XVII, âgé de dix ans et mort à la prison du Temple après une captivité de trois ans dont Françoise Chandernagor a fait récemment un récit bouleversant dans son roman La chambre. Et tout le reste est littérature ... (Mémorial, 2004). Daar bestaan dus geen moontlikheid van 'n vergissing nie: die hart wat in 2000 ondersoek is, is definitief dié van die tienjarige Lodewyk XVII wat in die Tempeltronk oorlede is na ' $n$ gevangeskap van drie jaar. Françoise Chandernagor het onlangs dié aangrypende verhaal vertel in "Die kamer". Die res is egter fiksie. 
'n Historiese en 'n biografiese roman deur twee Franse vroueskrywers sou uiteindelik die volle verhaal van Frankryk se mees tragiese kroonprins vertel. Chandernagor (2002:210) skilder die portret van 'n weeskind wie se ouers deur die vier mure van 'n tronkkamer vervang word en waar hy in donker afsondering die laaste maande van sy lewe deurbring:

Trouens, die Geskiedenis sou hom nie onthou as die seun van sy ouers nie, maar as die seun van hierdie mure: mense sou praat van die 'Toringkind', die 'Tempelkind' ...23

Chandernagor gee 'n literêre ekwivalent van Lodewyk-Karel se fisiese en sielkundige lyding en illustreer deur middel van die tema van verlies hoe hy geleidelik sy menslikheid verloor: die vier hoofdeugde (regverdigheid, krag, matigheid, behoedsaamheid) wat sy vroeë opvoeding gekenmerk het, het hulle betekenis verloor; sy verlede is ' $n$ verbode onderwerp; die buitewêreld is onbegaanbare terrein; herinnerings aan sy geliefde vader vervaag ("hy kan nie meer die kleur van sy oë onthou nie, maar wat sy buitelyn betref, meen hy dat daar miskien 'n ronding onder sy baadjie was" 24 (Chandernagor, 2002:32); hyself is naamloos ("hy het nie 'n naam gehad nie. In elk geval nie 'n naam waarvan hy absoluut seker was nie, een wat almal tegelykertyd sou tevrede stel nie"25 (Chandernagor, 2002:25).

De Bourbon Parme (2001), 'n afstammeling van Lodewyk XVII, ondersoek die genetiese band tussen haarself en die kroonprins se versteende hart. Wat hierdie biografiese roman en genealogiese meditasie iets besonders maak, is dat die outeur daarvan noodwendig van dieselfde bloedlyn moes wees. Lodewyk-Karel se hart (waarvan enkele millimeter met moeite afgesaag is) is in die eerste plek 'n stukkie versteende geheue waarin herinneringe aan die veldslae van Hendrik IV en die gloriedrome van die Sonkoning 26 (De Bourbon Parme, 2001:25) sluimer:

23 D'ailleurs, il n'entrera pas dans l'Histoire comme le fils de ses parents, il y entrera comme le fils de ces murs: on dira "I'Enfant de la Tour", “l'Enfant du Temple" ...

$24[\ldots]$ il ne retrouve plus la couleur de ses yeux, mais, pour ce qui est de la silhouette, il lui semble, en effet, qu'il était un peu gros sous sa veste.

25 II n'en avait pas. Pas de nom sûr du moins, et aucun qui pût plaire à tout le monde à la fois.

[...] le souvenir des batailles d'Henri IV et les rêves de gloire du Roi-Soleil [...]. 
Sou die hart onthou dat die mag van [Lodewyk-Karel] se vader van God afkomstig was, en dat die aartsbiskop van Reims en die gedaante van brood en wyn as bemiddelaars opgetree het? En dat sy grootmoeder keiserin van Oostenryk was?27

\section{Die wetenskap gee die deurslag}

Tussen 1999 en 2000 is 'n genetiese eksperiment in België, Frankryk en Duitsland uitgevoer wat bepaal het dat die versteende hart wel afkomstig was van 'n familielid van Marie Antoinette. Naundorff-ondersteuners beskou dit egter as die hart van die eerste kroonprins, Lodewyk-Josef, wat in 1789 oorlede is. Die geskiedenis van die twee harte verskil egter hemelsbreed. Lodewyk-Josef se hart

is op Christelike wyse verwyder en begrawe volgens 'n onveranderlike ritueel wat deel uitmaak van die Monargie se ware essensie; die tweede hart is in alleryl tydens die lykskouing verwyder, deur 'n arts wie se reputasie twyfelagtig en motiverings kompleks was 28 (Mémorial, 2004).

Vir die sensasiepers en die Naundorff-ondersteuners is daar nog onbeantwoorde vrae: "2 vase 2 harte waar is die kristalskerfies?" 29 (http://www.louis-xvii.com/plaquette.html, p. 3). Die pro-Naundorffwebwerf van die Lodewyk XVII-Instituut verwerp die amptelike bevinding en bevraagteken die egtheid van die orgaan asook die mening van die historikus Alain Decaux, Franse Akademielid en voormalige Naundorff-kampvegter.

DNS-toetse word al vir meer as vyftig jaar uitgevoer en het die deurslag gegee in opspraakwekkende sake soos die vasstelling van dokter Mengele se ware identiteit. Daar kan selfs gesê word dat identiteitskwessies soms meer oortuigend opgelos word deur DNStoetsing as deur biografiese navorsing, soos in die geval van Naundorff en Lodewyk XVII: 'n bedrieër sou dus beskryf kon word as 'n ouderwetse rariteit uit 'n voor-wetenskaplike era.

27 Se souviendrait-il que son père tenait son pouvoir de Dieu, par l'intermédiaire de l'archevêque de Reims et des saintes espèces? et que sa grand-mère était impératrice d'Autriche?

$28[\ldots]$ a été prélevé et enterré chrétiennement, selon un rite immuable et lié à l'essence même de la Monarchie; l'autre a été prélevé à la sauvette lors d'une autopsie, par un médecin de réputation douteuse et aux motivations complexes. 


\section{Die vertraagde teraardebestelling}

Die Franse publiek van 1795 was onbetrokke by die begrafnis van die kroonprins: daar was geen gebede of blomme nie, slegs 'n veertigtal handtekeninge onderaan ' $n$ versameling dokumente wat bevestig het dat die "koning" hierdie keer werklik dood was. Gravures en aandenkings met afbeeldings van gebreekte lelies en skoenlappers wat hemelwaarts vlieg, is wel per hand versprei.

Vanaf 1814 is herhaaldelike pogings aangewend om die kristalvaas 30 met die hart van Lodewyk XVII aan die Franse staat te skenk. Die reaksie was een van onverskilligheid en algemene wantroue. Pelletan is deur 'n oud-student beswadder en verdag gemaak by Lodewyk XVIII, wat die onbenydenswaardige posisie van opvolger van ' $n$ vermiste martelaarkoning beklee het. Lodewyk XVIII was bedag op swendelaars en vals relikwieë en het (soos sy broer Karel X, wat hom sou opvolg) geweier om die versteende orgaan in ontvangs te neem. In 1828 het 'n sterwende Pelletan die hart toevertrou aan die aartsbiskop van Parys, sy hoogwaardige eksellensie De Quélen. Gedurende die 1830-plundering van die aartsbisdom deur die Paryse gepeupel, is die vaas deur 'n sekere Lescroart gesteel. Hy het dit in stukke laat breek. Lescroart het Pelletan se seun (wie se naam in die bygaande dokumentasie vermeld is) van die verlies in kennis gestel, wat die versteende hart teruggevind het tussen die vullis waarmee die binnehof van die aartsbisdom bestrooi was. Die versteende hart en die skerwe van die eerste vaas is saam in 'n nuwe kristalhouer bewaar.

Met die dood van die jonger Pelletan in 1879, sou die hart aan die wettige troonopvolger geskenk word; die graaf van Chambord is egter oorlede voordat hy dit in ontvangs kon neem. Die nuwe erfgenaam, Édouard Dumont, skenk dit aan Don Carlos, die oudste van die Spaanse Bourbons, wat dit aan sy seun Jaime bemaak. Laasgenoemde bewaar die relikwie in die kapel van sy kasteel in Frohsdorf, Oostenryk. Die ongetroude Jaime bemaak die relikwie aan sy suster Béatrice, prinses Massimo, wie se dogter Marie-desNeiges dit skenk aan die Mémorial de France à Saint-Denys. ${ }^{31}$

30 Gravures van 'n hart omring met sonstrale, die naam "Lodewyk XVII", 'n kroon en 17 klein sterretjies verskyn op die vaas, terwyl die Franse lelie op die deksel gegraveer is.

31 Die Mémorial de France à Saint-Denys is verantwoordelik vir die mausoleum (praalgraf) van die Franse konings in die Saint-Denis katedraal en meer spesi- 
Inligting oor die teraardbestelling is byna eksklusief deur die elektroniese media versprei.32 Die seremonie is deur 2500 mense bygewoon; gebeure in die katedraal kon deur middel van reuseskerms op die kerkplein gevolg word. Ruikers wit blomme (lelies, rose en aronskelke: die kleur van die monargie) kon ook op die webwerf bestel word.33 'n DVD van die plegtigheid is kort daarna deur die Mémorial beskikbaar gestel.

Die seremonie het oor twee dae gestrek: op Maandag 7 Junie 2004 is die versteende hart van die laaste kroonprins van die Ancien Régime na die kerklike gemeente van die Franse konings (SaintGermain l'Auxerrois) gebring, waar 'n requiem-mis gehou is. Op 8 Junie is die relikwie deur die klerus van die koninklike nekropolis van Saint-Denis op die kerkplein in ontvangs geneem. 'n Plegtige mis is bygewoon deur sy Hoogeerwaarde Eminensie, Kardinaal Jean Honoré, emeritus Aartsbiskop van Tours en sy Hoogwaardige Eksellensie, Fortunato Baldelli, die apostoliese Nontius in Frankryk. Om drie-uur dieselfde middag het die hart uiteindelik sy plek in die Bourbon-kapel in die grafkelder van die basilika katedraal van SaintDenis gevind. Dit is dieselfde hart wat eeue vantevore deur dokter Pelletan gesteel, in 'n sakdoek toegedraai en in sy sak gedruk is; wat in die loop van meer as tweehonderd jaar vermis geraak en weer teruggevind is en ' $n$ voorwerp van verering en van spot was.

'n Postume "kroning"? Nouliks denkbaar! In 'n polities korrekte era het 'n régime wat deur sy ordetekens gedefinieer is geen reg op simbole nie. Op 8 Junie 2004 is geen vlae gehys nie: nie die wit vlag van die monargie óf die republikeinse driekleur nie. Die enigste vlae wat toegelaat is, was dié van "die betrokke families of die stede of streke van oorsprong van die vlagdraers"34 (http://www. memorialdefrance.org/venir.html). De Bourbon Parme (2001:24) merk egter tereg op dat vergete seremonies, waar mense 'n enkele

fiek vir die jaarlikse mis ter herdenking van die dood van Lodewyk XVI en Marie Antoinette.

32 Webwerf en e-posadres van die Mémorial de France à Saint-Denys: http://www.memorialdefrance.org en abonnement@memorialdefrance.org.

33 Die ruikerkatalogus het terme bevat wat 200 jaar laas gebruik is, soos die bloemiste Valérie Heim de Balsac se amp as "amptelike leweransier". 'n Keuse van drie ruikers is aangebied: 20 aronskelke (€20), 30 wit lelies (€30) of 40 wit rose $(€ 30)$.

[...] hors ceux des familles concernées ou villes et régions de provenance des personnes les portant. 
gebaar moet maak, in buitengewone omstandighede byna spontaan rondom 'n relikwie begin afspeel. 35

\section{Gevolgtrekking}

Die geskiedenis het geen tekort aan bedrieërs nie, maar die oorsprong van 'n volk se geloof in die onverganklikheid van 'n koningshuis is selfs interessanter as individuele gevalle van bedrog:

Onder het volk, of bij grote delen daarvan, is sprake van een utopisch wachten, van een geseculariseerd messiaans dynamisme, dat in de figuur van de valse pretendent zijn vervulling vindt36 (Petrie, 1995:12).

Mense reageer verskillend op die Tempeltronkraaisel en op die naam van Lodewyk XVII. Belangstelling word dikwels geïnterpreteer as ideologiese oortuiging of geringskatting van rewolusionêre weldade. Belangstelling word ook as onfatsoenlik beskou, in die lig van die groot aantal slagoffers van daardie stormagtige jare. Die lot van Lodewyk-Karel is egter tekenend van hoe terreur ontspoor het, en wys reeds vooruit na een van die euwels van die moderne tyd, naamlik kindermishandeling.

Lodewyk-Karel se ouers het moedig gesterf; die kroonprins het stoïsyns die lewe gelaat: sonder howelinge, sonder familie en sonder om 'n geluid te uiter. Op tienjarige ouderdom spreek dit van prinslike gedrag: miskien sou hy 'n goeie koning gewees het, wie weet? Lodewyk XVII se hart is in Saint-Denis en sy liggaam in Sainte-Marguerite. Terugskouend kan hierdie twee onthoofde heiliges wat die oorblyfsels van die laaste kroonprins van die Ancien régime bewaar, as ikone van die rewolusionêre periode beskou word. Madame De Staël37 (1996:58) het gesmeek:

$35[\ldots]$ parfois, dans des circonstances exceptionnelles, des cérémonies oubliées, où chacun n'a qu'un seul geste à faire, s'ordonnent presque spontanément autour d'une relique.

36 II est question chez le peuple ou une partie du peuple d'une attente utopique, d'un dynamisme messianique sécularisé, qui se réalise en la personne du faux prétendant.

37 Franse skryfster (1766-1617) en dogter van Necker, die Switsers-gebore direkteur-generaal van Finansies van Lodewyk XVI. 
Verdedig die Koningin met alle wapens waaroor die natuur beskik; gaan red daardie kind: hy sal sekerlik sterf as hy [die moeder] moet verloor wat hom so verskriklik liefgehad het. 38

Al wat Marie Antoinette op haar selmuur in die Tempeltronk geskryf het, was hoe lank haar seun was. Toe hy van haar af weggeneem is, het die koningin ure lank voor 'n klein venstertjie gestaan vanwaar sy hom in die binnehof kon sien speel. Toe sy in Augustus 1793 die Tempeltronk vir die Conciergerie 39 moes verruil, wou sy haar seun vir oulaas omhels, maar die versoek is deur die sipiers geweier. Haarmonsters van Marie Antoinette, Maria-Josepha en Johanna-Gabriela (twee van haar susters, wie se haarlokkies bewaar gebly het in die medaljons van 'n gebedsnoer), wat die mitokondriale DNS (afkomstig van die moeder) aan Lodewyk-Karel en aan 'n veraf afstammeling, Anna van Roemenië, oorgedra het, het gelei tot die identifikasie van sy versteende hart.

Lodewyk XVII sou nooit weet dat dit vir sy moeder veel moeiliker was om haar geliefde chou d'amour (liefste skatjie) te verlaat as om die skavot te bestyg nie. Ironies genoeg sou die raaisel rondom die lot van die laaste kroonprins van die Ancien Régime nie opgelos kon word sonder dokter Pelletan se orgaanroof nie:

Whatever the motive that prompted dr. Philippe-Jean Pelletan to steal the child's heart - whether royal fervour, curiosity, or a desire to make money - it is ironic that an act of thievery should lead, two hundred years later, to such a satisfactory resolution. As Pelletan had consistently maintained, the child who lived and died alone and in such misery in the temple, unrecognisable as a royal prince and heir, his sickly body covered in sores and ulcers, was indeed the ten-year-old Dauphin. At last, the tragic circumstances of Louis-Charles' death had been proved to the world (Cadbury, 2002:283).

\section{Geraadpleegde bronne}

CADBURY, DEBORAH. 2002. The lost king of France: revolution, revenge and the search for Louis XVII. London: Fourth Estate.

CHANDERNAGOR, FRANÇOISE. 2002. La chambre. Paris: Gallimard.

38 Défendez la Reine par toutes les armes de la nature; allez chercher cet enfant, qui périra s'il faut qu'il perde celle qui l'a tant aimé.

39 Die Middeleeuse deel van die Paleis van Justisie in Parys, vanwaar Marie Antoinette na die guillotine geneem is. 
COPPOLA, SOFIA. 2006. Marie Antoinette. Columbia Pictures. DVD 0520. (ISBN/ISSN: 3388330030902.)

DE BOURBON PARME, AMÉLIE. 2001. Le sacre de Louis XVII. Paris: Gallimard.

DE SAINT-EXUPÉRY, ANTOINE. 1979. Le petit prince. Paris: Gallimard.

DE STAËL, MADAME GERMAINE. 1996. Réflexions sur le procès de la reine. Paris: Mercure de France.

FRASER, ANTONIA. 2001. Marie Antoinette. London: Weidenfeld \& Nicolson.

http://www.expatica.com/source/site_article.asp?subchannel_id=58\&story_id $=8305$ Date of access: 5 Feb. 2007.

L'INSTITUT LOUIS XVII. 2007. Contre le projet d'inhumation sous une fausse identité du cœur de l'enfant du Temple. http://www.louis-xvii.com/ plaquette.html [5 fév. 2007].

MÉMORIAL DE FRANCE À SAINT-DENYS. 2004. Cérémonies solennelles déposition du cœur de Louis XVII dans la Chapelle des Bourbons en la cathédrale basilique de Saint-Denis. DVD, Éditions Longs \& Merveilles. http://www.memorialdefrance.org/science/html [23 fév. 2004].

MORGAN, NAÒMI. 2001. Die roman maak geskiedenis: Jozef Simons se Eer Vlaanderen vergaat. Acta Academica, 33(3):67-109.

PETRIE, J.H. 1995. Lodewijk XVII - Naundorff: een mysterie ontrafeld. Amsterdam: De Bataafsche Leeuw.

ZAAL, WIM. 1995. Onnozele kinderen - Lodewijk XVII, Victor van Aveyron, Kaspar Hauser. Amsterdam: De Arbeiderspers.

\section{Kernbegrippe:}

biografie

Franse Rewolusie

historiese roman

Lodewyk XVII

Marie Antoinette

\section{Key concepts:}

biography

French Revolution

historical novel

Louis XVII

Marie Antoinette 


\section{Portretbylaag}

\section{Portret 1:}

Lodewyk XVII deur Kucharski (faksimilees van die vier portrette in Petrie, J.H. 1995. Lodewijk XVII - Naundorff. Een mysterie ontrafeld. Amsterdam: De Bataafsche Leeuw)

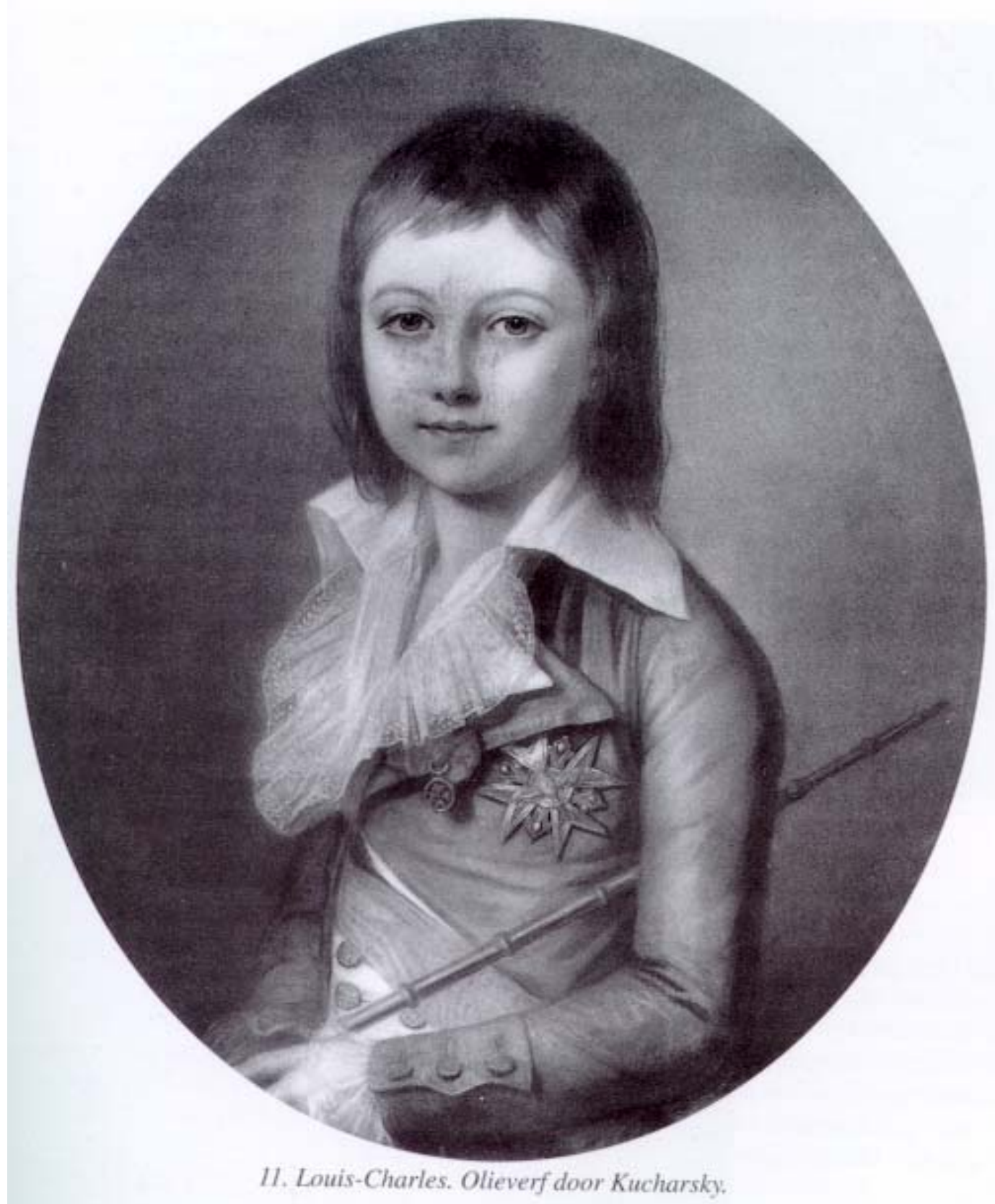




\section{Portret 2:}

Lodewyk XVII deur David

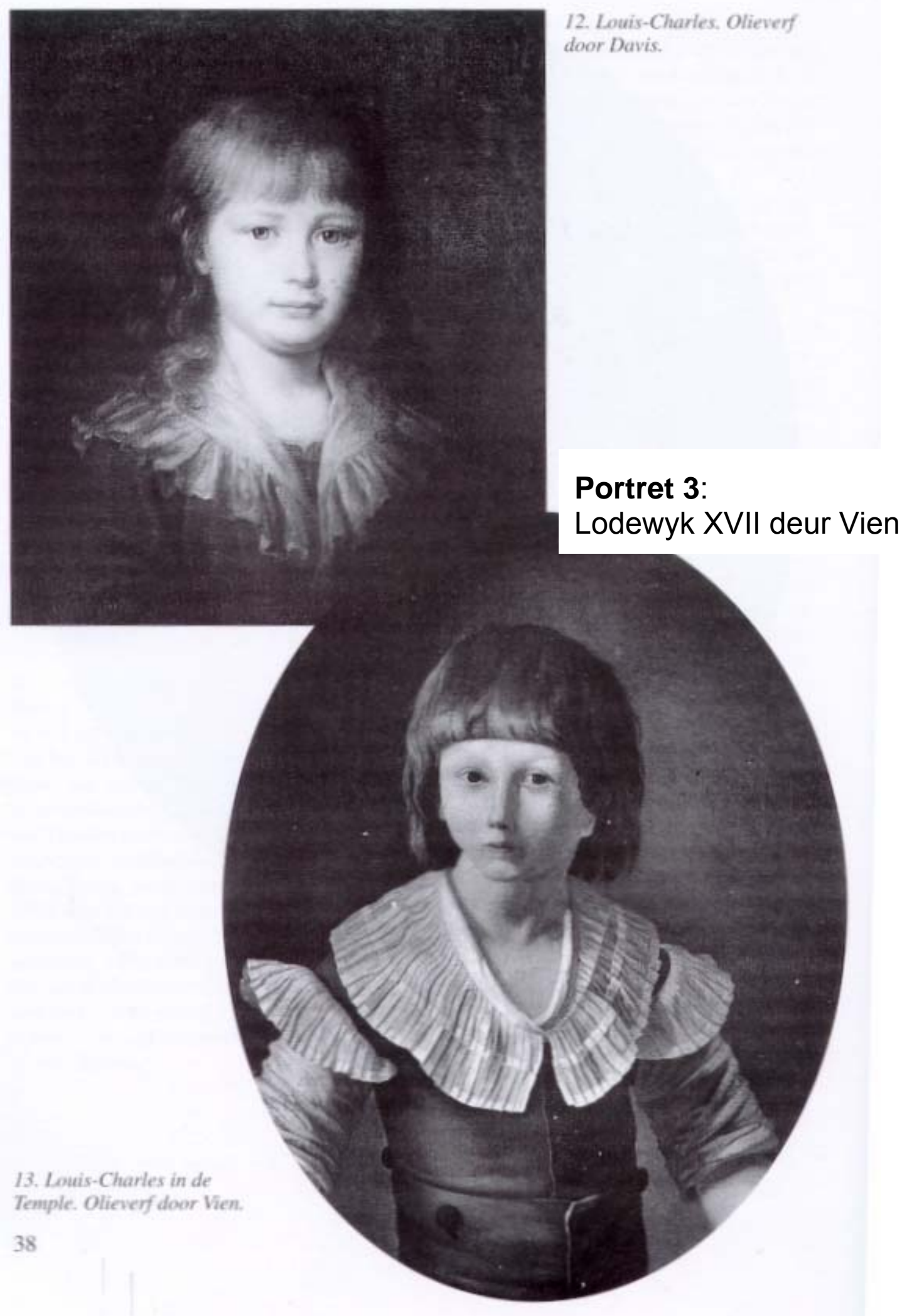




\section{Portret 4:}

Lodewyk XVII deur Moriès

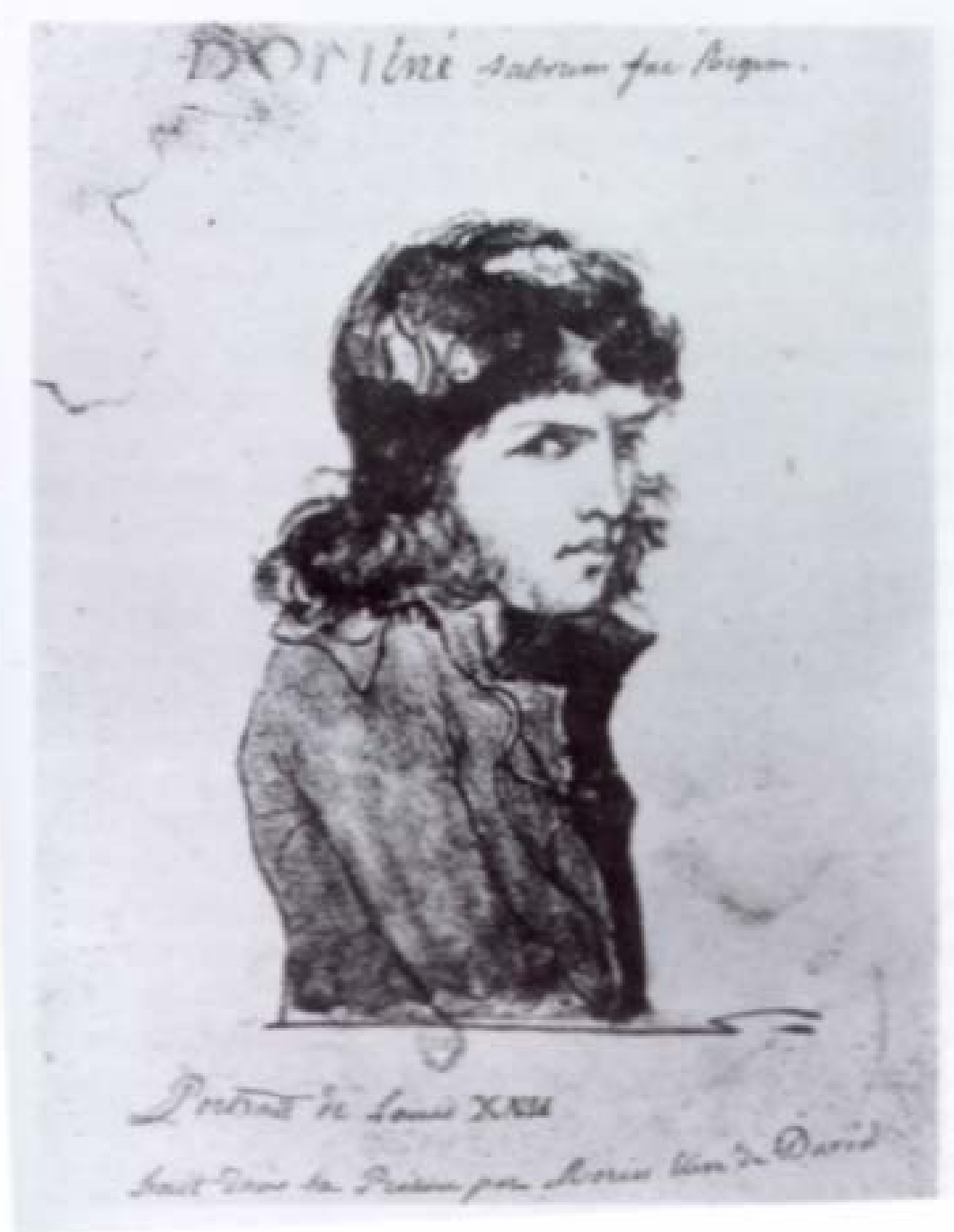


